\title{
Review of High-Temperature Central Receiver Designs for Concentrating Solar Power
}

Brian D. Iverson

Brigham Young University - Provo, bdiverson@byu.edu

Clifford K. Ho

Follow this and additional works at: https://scholarsarchive.byu.edu/facpub

Part of the Mechanical Engineering Commons

\section{Original Publication Citation}

Ho, C. K. and Iverson, B. D., 2014, "Review of high-temperature central receiver designs for concentrating solar power," Renewable \& Sustainable Energy Reviews, Vol. 29, pp. 835-846. doi:10.1016/j.ser.2013.08.099

\section{BYU ScholarsArchive Citation}

Iverson, Brian D. and Ho, Clifford K., "Review of High-Temperature Central Receiver Designs for Concentrating Solar Power" (2014). Faculty Publications. 1568.

https://scholarsarchive.byu.edu/facpub/1568 


\title{
Review of High-Temperature Central Receiver Designs for Concentrating Solar Power
}

\author{
Clifford K. Ho and Brian D. Iverson \\ Sandia National Laboratories \\ Concentrating Solar Technologies Department \\ P.O. Box 5800 \\ Albuquerque, NM 87185-1127, USA \\ (505) 844-2384, ckho@sandia.gov
}

\begin{abstract}
This paper reviews central receiver designs for concentrating solar power applications with high-temperature power cycles. Desired features include low-cost and durable materials that can withstand high concentration ratios ( $\sim 1000$ suns), heat-transfer fluids that can withstand temperatures $>650^{\circ} \mathrm{C}$, high solar absorptance, and low radiative and convective heat losses leading to a thermal efficiency $>90 \%$. Different receiver designs are categorized and evaluated in this paper: (1) gas receivers, (2) liquid receivers, and (3) solid particle receivers. For each design, the following information is provided: general principle and review of previous modeling and testing activities, expected outlet temperature and thermal efficiency, benefits, perceived challenges, and research needs. Emerging receiver designs that can enable higher thermal-toelectric efficiencies (50\% or higher) using advanced power cycles such as supercritical $\mathrm{CO}_{2}$ closed-loop Brayton cycles include direct heating of $\mathrm{CO}_{2}$ in tubular receiver designs (external or cavity) that can withstand high internal fluid pressures $(\sim 20 \mathrm{MPa})$ and temperatures $\left(\sim 700^{\circ} \mathrm{C}\right)$. Indirect heating of other fluids and materials that can be stored at high temperatures such as advanced molten salts, liquid metals, or solid particles are also being pursued, but challenges include stability, heat loss, and the need for high-temperature heat exchangers.
\end{abstract}

Keywords: concentrating solar; receiver; volumetric; external; cavity; solid particle 


\section{Introduction}

Higher efficiency power cycles are being pursued to reduce the levelized cost of energy from concentrating solar power tower technologies [1]. These cycles, which include air-Brayton, supercritical- $\mathrm{CO}_{2} \quad\left(\mathrm{sCO}_{2}\right)$ Brayton, and ultra-supercritical steam cycles, require higher temperatures than those previously achieved using central receivers. Current central receiver technologies employ either water/steam or molten nitrate salt as the heat-transfer and/or working fluid in subcritical Rankine power cycles. The gross thermal-to-electric efficiency of these cycles in currently operating power-tower plants is typically between 30 and $40 \%$ at inlet temperatures $<600{ }^{\circ} \mathrm{C}$. At higher input temperatures, the thermal-to-electric efficiency of the power cycles increases following Carnot's theorem. However, at temperatures greater than $600{ }^{\circ} \mathrm{C}$, molten nitrate salt becomes chemically unstable, producing oxide ions that are highly corrosive [2], which results in significant mass loss [3].

\subsection{Key Technical Challenges}

Unique challenges associated with high-temperature receivers include the development of geometric designs (e.g., dimensions, configurations), materials, heat-transfer fluids, and processes that maximize solar irradiance and absorptance, minimize heat loss, and have high reliability at high temperatures over thousands of thermal cycles. In addition, consideration must be given to advantages and disadvantages of direct vs. indirect heating of the power cycle working fluid. For example, advantages of direct heating of the working fluid include reduced exergetic losses through intermediate heat exchange. Advantages of indirect heating include the ability to store the heat transfer media (e.g., molten salt, solid particles) for energy production during non-solar hours. In addition, heat addition to the receiver media (through exposure to the heat source) can also be done directly (e.g., exposed liquid films or solid particles) or indirectly 
(e.g., tubular receivers).

Regarding reduction of heat losses to achieve high thermal efficiencies, Eq. (1) presents the receiver thermal efficiency, $\eta_{t h}$, as a function of the incoming solar radiative power, $Q_{i n}(\mathrm{~W})$, and the radiative and convective heat losses, $Q_{\text {loss }}(\mathrm{W})$ :

$$
\eta_{\text {th }}=\frac{\alpha Q_{\text {in }}-Q_{\text {loss }}}{Q_{\text {in }}}=\alpha-\frac{\varepsilon \sigma F_{\text {view }} T_{R}^{4}+f_{\text {conv }} h\left(T_{R}-T_{\text {amb }}\right)}{\eta_{\text {field }} E_{D N I} C}
$$

where $\alpha$ is the receiver solar absorptance, $\varepsilon$ is the receiver thermal emittance, $\sigma$ is the Stefan-Boltzmann constant $\left(5.67 \times 10^{-8} \mathrm{~W} / \mathrm{m}^{2} \cdot \mathrm{K}^{4}\right), F_{\text {view }}$ is the radiative view factor from the receiver surface to the surroundings, $T_{R}$ is the receiver surface temperature $(\mathrm{K}), f_{\text {conv }}$ is a convective heat loss multiplier, $h$ is the convective heat transfer coefficient, $T_{a m b}$ is the ambient temperature $(\mathrm{K}), \eta_{\text {field }}$ is the heliostat field efficiency (including cosine losses, reflectance losses, and spillage), $E_{D N I}$ is the direct normal irradiance $\left(\mathrm{W} / \mathrm{m}^{2}\right)$, and $C$ is the concentration ratio. Assuming an absorptance, $\alpha$, of 0.95 [4, 5], a thermal emittance, $\varepsilon$, of 0.85 [4], an ambient temperature, $T_{a m b}$, of $20^{\circ} \mathrm{C}$, and an annual heliostat field efficiency, $\eta_{\text {field }}$, of 0.6 [6], plots of the thermal efficiency, $\eta_{t h}$, as a function of receiver temperature, $T_{R}$, with varying values of concentration ratio, $C$, radiative view factor, $F_{\text {view }}$, and convective heat loss factor, $f_{\text {conv }}$, can be generated (Figure 1). Values from Solar Two are used as baseline inputs. The average flux on the Solar Two receiver was $430 \mathrm{~kW} / \mathrm{m}^{2}$ [5], so the baseline concentration ratio, $C$, is calculated (using the denominator in Eq. (1)) to be $~ 900$ assuming a field efficiency of 0.6 [6] and an average direct normal irradiance of $0.8 \mathrm{~kW} / \mathrm{m}^{2}$ (approximated from data in [5]). In addition, the estimated baseline value for the convective heat transfer coefficient, $h$, is $10 \mathrm{~W} / \mathrm{m}^{2}-\mathrm{K}[5,7]$, the baseline convective heat loss factor, $f_{\text {conv }}$, is one, and the baseline radiative view factor is one. 


\section{Figure 1. Plots of receiver thermal efficiency as a function of receiver surface temperature with varying concentration ratio (a), radiative view factor (b), and convective heat loss (c).}

The plots in Figure 1 show that a high concentration ratio $(\mathrm{C}>900)$ on the receiver and a reduced radiative view factor $\left(F_{\text {view }}<1\right)$ are critical to maintain high thermal efficiencies at temperatures above $650{ }^{\circ} \mathrm{C}$. Reducing the convective heat loss is less significant, although it can yield a several percentage point increase in thermal efficiency at high temperatures (note that the convective heat loss in cavity receivers can be a factor of two or more greater than that in external receivers because of the larger absorber area [6]). Increasing the solar absorptance, $\alpha$, and/or decreasing the thermal emittance, $\varepsilon$, in Eq. (1) will also increase the thermal efficiency.

\subsection{Overview of Paper}

Three categories of high-temperature solar central receivers are reviewed in this paper: (1) gas receivers, (2) liquid receivers, and (3) solid particle receivers. In each category, the following information is provided:

- General principle and review of previous modeling and testing activities

- Expected outlet temperature and thermal efficiency

- Benefits and perceived challenges

- Research needs

\section{Gas Receivers}

\subsection{Volumetric Air Receivers}

Volumetric air receivers have been under development since the 1980's and typically employ porous structures (e.g., honeycombs, porous ceramics) that are irradiated by concentrated sunlight. Air flows through the porous structure and is heated to temperatures between $800-$ 
$1000{ }^{\circ} \mathrm{C}$ for metals, up to $1200^{\circ} \mathrm{C}$ for ceramics, and up to $1500{ }^{\circ} \mathrm{C}$ for $\mathrm{SiC}$ [8]. The air can then be used to heat a separate working fluid (e.g., for a Rankine steam cycle) [9], charge a storage medium [10], or pass directly into a gas turbine. The two basic applications of volumetric air receivers are (1) open-loop atmospheric receiver system for a Rankine cycle and (2) closed-loop pressurized (windowed) receiver system for a Brayton Cycle. Avila-Marin [8] provides a comprehensive review of volumetric receivers up to 2010. Some highlights are presented below.

Chavez and Chaza [11] report on the design and testing of a porous ceramic absorber at the Plataforma Solar de Almeria in Spain in 1991. The peak flux on the absorber was greater than $800 \mathrm{~kW} / \mathrm{m}^{2}$, and the peak mean outlet air temperature was $730{ }^{\circ} \mathrm{C}$. The mean absorber efficiency was $\sim 65 \%$ at an outlet temperature of $\sim 550{ }^{\circ} \mathrm{C}$, but the thermal efficiency decreased to $\sim 54 \%$ at a peak mean outlet temperature of $730{ }^{\circ} \mathrm{C}$. The authors state that the design was not optimized, and that several factors (such as the Pyromark paint being too thick and blocking some of the pores) reduced the efficiency. In addition, the absorber material temperature was measured to be $1350^{\circ} \mathrm{C}$ at a peak mean outlet temperature of $730{ }^{\circ} \mathrm{C}$, leading to large radiative heat losses. The authors estimated that with an optimized absorber, an absorber efficiency of 80 $-85 \%$ at $550{ }^{\circ} \mathrm{C}$ could be attained.

To reduce radiative heat losses, Menigault et al. and Variot et al. $[12,13]$ proposed a two-slab selective volumetric receiver in which the irradiated front slab was composed of solar transparent glass beads or a silica honeycomb, and the second slab was composed of silicon carbide particles. The principle of this semitransparent multilayer system was to allow solar radiation to penetrate through the first slab into the second slab. Infrared emission from the second slab was absorbed by the material in both slab one and two. As a result, the location of maximum temperature was within the interior of the volumetric absorber which decreases 
radiative heat loss. Results of testing at the solar furnace in Odeillo, France, showed that for a windowed receiver, thermal efficiencies of near $90 \%$ with gas outlet temperatures of close to $700^{\circ} \mathrm{C}$ could be attained. Pitz-Paal et al. [14] also described a similar concept employing square glass channels that cover a ceramic foil receiver. Their modeling results showed that the efficiency could be improved by up to $10 \%$ at gas outlet temperatures up to $1000{ }^{\circ} \mathrm{C}$ relative to pure ceramic receivers.

Marcos et al. [15] described the need to increase the air return ratio, or the ratio of the air mass flow re-fed through the volumetric receiver to the total air mass flow through the receiver. Recapturing the waste heat contained in the exhaust air after the thermal energy has been transferred to the working fluid of the power cycle is critical to increasing the thermal efficiency of air-cooled solar thermal receivers. They reported that current scaled-up air-return ratios are between 45 and $70 \%$, which translates to energy losses of 5 to $15 \%$. By optimizing the air injection and geometrical properties of the absorber through computational fluid dynamics simulations, the authors found that some parts of the receiver could achieve air-return ratios above $90 \%$, but average values were simulated to be $\sim 70 \%$.

The potential for unstable flow and non-uniform heating in the volumetric receiver, leading to overheating and local failures in the receiver material is another challenge for volumetric air receivers $[16,17]$. The instabilities are caused by changes in temperaturedependent air properties (viscosity and density), but the instabilities may be mitigated by using low-porosity absorber materials. Karni et al. describe the use of a volumetric solar receiver employing ceramic pins, called a "Porcupine," that showed the capability to achieve gas temperatures near $1000^{\circ} \mathrm{C}[18]$. 


\subsection{Small Particle Air Receivers}

In small particle air receiver designs, submicron carbon particles are suspended in air and heated by concentrated sunlight in a pressurized cavity air-receiver. The energy is transferred to the pressurized air in the receiver for high-temperature Brayton cycles $[19,20]$. This heatexchanger concept using solid-gas suspensions was first conceived in the 1970's [21, 22]. Potential advantages include the following: solar radiation is absorbed throughout the gas volume due to the large cumulative surface area of the particles; higher incident fluxes with no solid absorber that can be damaged; particles are oxidized leaving a particle free outlet stream [19]. Theoretical studies have shown that the receiver efficiency can reach up to $\sim 90 \%$ depending on parameters such as particle size, particle concentration, optical properties of the particles and window, mass flow rate, and temperature $[19,20]$. Experiments conducted with a $25 \mathrm{~kW}_{\text {th }}$ small-particle receiver showed that air could be heated to $700{ }^{\circ} \mathrm{C}$ [23]. Challenges include the development of a suitable window for the pressurized receiver and the development of a solid-gas suspension system that maintains a desired particle concentration and temperature within the receiver.

\subsection{Tubular Gas Receivers}

High-temperature solar thermal receivers have been proposed for air-Brayton cycles since the 1970's, and prototypes have been developed and tested in recent years [24-33]. Early receiver designs were for parabolic dish receivers and employed liquid-metal heat pipes to improve exchange heat from the solar irradiance to the gas [24]. The internal heat-transfer coefficient in a liquid-metal heat pipe is on the order of $30,000 \mathrm{~W} / \mathrm{m}^{2} \cdot \mathrm{K}$ ) compared to 300 $\mathrm{W} / \mathrm{m}^{2} \mathrm{~K}$ for heat transfer to gases [24]. Therefore, higher solar fluxes can be tolerated with heat pipes yielding more compact receivers, lower metal temperatures, and lower pressure drops. 
Disadvantages include potentially higher receiver costs. Design specifications included an airoutlet temperature of $815{ }^{\circ} \mathrm{C}$ with an air-inlet temperature of $565^{\circ} \mathrm{C}$, air mass flow rate of 0.24 $\mathrm{kg} / \mathrm{s}$, pressure drop of $2 \%$, and thermal efficiencies up to $85 \%$ [24].

More recent designs and tests have been conducted by DLR for a solar-hybrid microturbine system operating in a central receiver for applications on the order of $100 \mathrm{~kW}-1$ MW [26, 28-30, 32]. Design concepts introduced in these studies include the use of absorber tubes with a "Profiled-Multi-Layer" design consisting of Inconel material with copper sandwiched in between in a hydroforming process to enhance the circumferential heat distribution and heat transfer to the gas, segmented silica windows to reduce convective and radiative heat losses, and hybridization (Figure 2). Simulations showed an increase in the potential thermal efficiency of the receiver from $68 \%$ to $81 \%$ when a window was used compared to simulations with no window. Tests performed at the Plataforma Solar de Almeria using the system in Figure 2 showed a smaller improvement from $40 \%$ (no window) to $43 \%$ (window) with receiver inlet and outlet temperatures of $\sim 600{ }^{\circ} \mathrm{C}$ and $\sim 800{ }^{\circ} \mathrm{C}$, respectively, a turbine power of $\sim 70 \mathrm{~kW}$, and a solar input of $273 \mathrm{~kW}$ [32]. Discrepancies between the simulated and measured values were caused by heat loss through the cavity walls and smaller than expected mass flow through the turbine.

Figure 2. Design concepts from DLR: (a) tubular air-turbine receiver, (b) multi-layer tube with copper in between Inconel, (c)-(d) segmented parts of glass tubes to form a window on the receiver aperture, and (e) schematic of receiver and microturbine on top of a tower [29, 30, 32].

In addition to challenges associated with large convective and radiative heat losses from these receivers operating at higher temperatures and the difficulty in transferring the heat effectively from the irradiated tubes to the gas, high-temperature tubular receivers are subject to 
rapid transient thermomechanical loads that can adversely affect the fatigue life of the receiver. Uhlig conducted tests and developed a Chaboche-type plasticity model to predict the fatigue life of nickel-based alloy tubes subject to transient thermal stresses. The model was used to redesign receiver components to reduce the stresses [33]. Kolb compiled low-cycle fatigue data for Incoloy $800 \mathrm{HT}$, Inconel 625-LCF, and Haynes 230 alloys and performed analyses to determine allowable flux limits on these materials (albeit for molten-salt power tower plants) [34].

With increasing interest in $\mathrm{sCO}_{2}$ Brayton cycles that can attain thermodynamic efficiencies above $50 \%$ at concentration ratios and temperatures achievable by concentrating solar [35-41], $\mathrm{sCO}_{2}$ has been proposed for use as a heat transfer fluid in CSP systems [42, 43]. Tubular receivers that employ $\mathrm{sCO}_{2}$ as the heat transfer fluid are a likely possibility as the small diameter tubes may enable the high pressures required for the supercritical phase. At the turbine inlet, pressures on the order of 15-25 MPa may be expected for $\mathrm{sCO}_{2}$ Brayton. One challenge of using $\mathrm{sCO}_{2}$ as the receiver heat transfer fluid is integration with storage; thermal storage of supercritical fluids has been shown to not be a viable option [44], thus requiring intermediate heat exchange with a separate storage media if $\mathrm{sCO}_{2}$ is to be used in the receiver. Analysis and demonstration of $\mathrm{sCO}_{2}$ receivers for CSP is anticipated to be at the forefront of receiver advances being pursued for tower configurations today. Additional studies for a $\mathrm{CO}_{2}$ pipe receiver for parabolic trough exist at lower temperatures and pressures than that anticipated for towers [45].

\section{Liquid Receivers}

\subsection{Tubular Liquid Receivers}

Tubular liquid central receiver systems have been studied since the 1970's and were first implemented in the 1980's and 1990's in demonstration plants with Solar One and Solar Two [5, 
46]. Conventional tubular receivers consist of an array of thin-walled tubes (stainless steel or alloyed) that are typically arranged to shuttle the working fluid (e.g. water/steam or molten salt) in multiple passes through incident concentrated sunlight. The fluid is then transported to storage or to the power block. Both external and cavity-type receivers have been considered for use with tubular receivers (see Figure 3ab). Liquid-based, tubular receivers, such as those that employ a molten salt, are very similar to current power tower receiver design approaches and have been examined extensively at Sandia National Laboratories [47, 48], Themis [49] and Plataforma Solar de Almeria [50]. Temperatures of the heat transfer fluid exiting the receiver have been less than approximately $600{ }^{\circ} \mathrm{C}$ to date. At elevated temperatures of $650-750{ }^{\circ} \mathrm{C}$, reradiation effects must be considered in order to select an open or an enclosed receiver design. Liquid sodium [6] and fluoride-salt [51] heat-transfer fluids have also been proposed as an alternative to molten nitrate salt to achieve higher temperatures and efficiencies. Higher thermal conductivities associated with liquid metals allows for higher incident flux levels (in excess of $1.5 \mathrm{MW} / \mathrm{m}^{2}$ ), as the thermal conductivity reduces the front-to-back receiver tube temperature and associated thermal stresses [6]. Higher incident heat flux also increased thermal efficiency of the receiver as a smaller receiver can be constructed for the same thermal power collected.

\section{Figure 3. Schematics of tubular (left) external and (right) cavity receivers.}

Tube size and wall thickness are selected to maximize heat transfer while minimizing pumping losses. The heat transfer coefficient scales as $1 /$ diameter, making small diameters attractive for convection. However, pumping losses and material costs increase and required wall thicknesses decrease at a given pressure with smaller diameters, resulting in an optimum diameter [47]. Tubular receiver designs are commonly comprised of several panels, which are in turn comprised of an array of tubes. Tubes in the same panel have fluid flows in the same 
direction and have approximately the same flux distribution. The use of numerous tubes effectively acts as a mechanism to enhance heat transfer, much like fins are used to increase surface area.

Estimated efficiencies for an external, tubular receiver employing a variety of working fluids (including high temperature $\mathrm{HTFs}$ such as $\mathrm{LiCl} / \mathrm{KCl}$ and $\mathrm{Na}$ ) indicate values in the $84 \%$ $89 \%$ range appear achievable $[48,52]$, with design point operation reaching above $90 \%[6,48]$. Final evaluation results of Solar Two's receiver indicate similar values and has become a standard for comparison (see Figure 4). Additional fluids must also be considered (such as the fluorides [53]) in order to achieve reasonable working fluid melting points and higher thermal conductivities that will improve efficiency. The fluid type is a limiting factor in the receiver operating temperature that, in turn, drives receiver efficiency. Incorporating a selective absorption technique that improves or maintains the absorptivity while reducing emissivity can provide a significant boost to efficiency and reduce losses to achieve efficiency targets $[34,54$, $55]$.

Receiver design is highly dependent on the selected working fluid used to convey the absorbed thermal energy. Liquid-based receivers have high heat-transfer rates and high specific heat relative to gaseous HTFs. Numerous HTFs have been tested to date for use in receiver systems including water/steam [56], nitrate salt [5], and sodium [50]. Water/steam systems at elevated temperatures have been deployed at pilot facilities such as Solar One and PS10 and PS20. For systems that operate with conventional steam cycles, the turbine inlet conditions are commonly 9-13 $\mathrm{MPa}[6]$. One concern for steam above $650{ }^{\circ} \mathrm{C}$ is the enormous pressures required for the supercritical phase. Solar Two employed the use of an external tubular receiver with a molten nitrate salt working fluid that could accommodate fluxes of approximately 850 
$\mathrm{kW} / \mathrm{m}^{2}$, nearly 3 times larger than the $300 \mathrm{~kW} / \mathrm{m}^{2}$ flux of Solar One [57]. Using nitrate salt as the receiver HTF is also appealing because the same fluid can be used as the storage medium, eliminating the need for an intermediate heat exchanger between the receiver and thermal storage. A significant limitation in going to higher temperatures is the concern for nitrate salt mass loss (decomposition) occurring when temperatures climb above $600-630{ }^{\circ} \mathrm{C}$. Below this temperature, the mass loss is relatively constant and can be managed successfully; above this temperature the mass loss begins to increase dramatically [3]. In the case of sodium or other liquid metal HTFs, reactivity with oxygen, combined with the potential for leaking, can be a concern.

\section{Figure 4. Calculated and measured receiver efficiency as a function of wind speed for Solar Two (from [5]).}

Consideration of alternative fluid choices has begun to appear in the literature with many unanswered questions regarding their behavior and implementation. One concept that has surfaced is the possibility of employing fluoride salts as the working fluid in a tower receiver [53]. Fluorides have been investigated for use in molten salt nuclear reactors such as a thermalneutron breeder reactor. They are typically stable in liquid form below $1000{ }^{\circ} \mathrm{C}$, which allows for low-pressure, liquid-phase handling and transport. Chloride salts have also received attention, though corrosion becomes a primary concern at elevated temperatures where an increase would be expected in an Arrhenius fashion [52]. A benefit to the chloride salts is that they are considered environmentally benign [58]. Carbonate salts have also been suggested due to their material compatibility and affordability. Carbonate salts create stable oxide layers (unlike fluorides [59] and chlorides [60-62]) that act as a protective barrier for the base alloys and have been found, under most conditions, to be considerably less aggressive with respect to 
corrosion [63]. Carbonates will suffer from salt degradation at high temperatures, where the carbonate anion decomposes into carbon dioxide and oxide, similar to what is observed for nitrate salts above $600{ }^{\circ} \mathrm{C}[64,65]$. Fluorides and chlorides do not experience deterioration in this manner due to their simple anion structure. For liquid metals and salts, consideration must be given during design and operation to the potential for solidification when melt temperatures are above ambient. This concern is especially critical during startup, shutdown, and transient operation [66-68]. Higher receiver fluid conductivity (such as for sodium) enables higher allowable peak flux, thereby reducing the receiver size for the same allowable peak flux (see Figure 5b). In addition to accelerated corrosion due to interaction with the working fluid, another concern at high temperatures is fatigue in the receiver/storage system materials. Current efforts are underway at Sandia National Laboratories to investigate isothermal, cyclic fatigue at elevated temperatures (up to $\sim 650^{\circ} \mathrm{C}$ ) with Haynes 230 for the benefit of the CSP industry. This is critical in determining cycles to failure for the daily cycling through startup and shutdown as well as shorter transients such as cloud cover. Fatigue analysis using SS316 using weather data has been performed and similar studies have been initiated to investigate additional containment materials $[47,69,70]$.

Analysis on both external-type and cavity-type receivers has been conducted [71] with cavity receivers generally expected to have a lower radiation heat loss and higher convective heat loss than that for external receivers [6]. Towers for surround field systems are shorter than the tower required for a north-field design. However, a larger land area is required for surround fields than for north-facing fields (see Figure 5). The impact of receiver area, thermal losses (including emissive, convective, reflective and conductive), number of receiver tubes in a panel, tube diameter and surface temperature for a molten salt cavity receiver have been calculated with 
benchmarked models [57]. Experimental demonstrations of tubular receiver panel performance has also been conducted with slightly lower thermal efficiencies obtained for external-type receivers [72]. As described in Section 1.1, selective absorber coatings for high-temperature central receivers that increase the solar absorptance while minimizing thermal emittance can increase the thermal efficiency. Desired features for these solar selective absorber coatings include stability at high-temperatures in air, high durability (must withstand thousands of thermal cycles), low cost, and ease of application. Optical properties of commercial high-temperature paint (Pyromark 2500) has been characterized [4, 73], and other coating materials and deposition methods have also been evaluated for use in high-temperature central receiver applications $[74$, 75].

Figure 5. (a) Schematic of a tubular panel and (b) relative tower heights/receiver sizes for a liquid sodium and molten salt tubular receivers (from [6]).

\subsection{Falling-Film Receivers}

Falling-film receivers are characterized by gravity-driven fluid motion in the receiver. The fluid typically flows down an inclined wall and can either be directly irradiated or indirectly heated through the wall. This approach reduces the pumping requirement in the receiver.

Direct exposure falling-film receivers exploit absorption of the thermal energy directly by the receiver working fluid and reduces thermal resistance. Commonly, this approach has been referred to as a Direct Absorption Receiver (DAR) where the fluid is illuminated as it falls down an internal (cavity) or external wall. Blackened molten nitrate salts (using suspended submicron particles) have been considered for these fluids so as to improve absorption in the liquid film [76]. An optimum fluid layer opacity appears to exist for collection to maximize efficiency; optically thin layers of fluid do not adequately absorb direct illumination while opacities greater 
than the critical fluid layer thickness absorb near the surface resulting in greater emission [77]. Addition of oxide dopants has been considered in molten salts to increase volumetric absorption in the transport fluid with reports of optical absorption properties with and without dopants reported in the literature [78-81]. One study with cobalt oxide has been shown to increase receiver efficiencies by $4.4 \%$ but questions its justification on an economic basis [82]. A more recent study investigated suspended nanoparticles to absorb radiation and developed an analytical model to determine the effect of heat loss, particle loading, solar concentration and channel height on receiver efficiency [83]. Release of nitrogen dioxide has been used as a mechanism to determine the stability of nitrate and nitrite molten salts in the presence of oxide additives to improve absorption [84]. Film stability has been studied in numerous direct absorption receiver designs but demonstrations have been with water under isothermal conditions [76, 77, 85-88]. Analytical studies have been reported of heat and mass transfer in wavy liquid films [89] and falling turbulent films [90, 91]. A correlation to predict the heat flux required to break a falling liquid film (thermocapillary breakdown) has also been reported [92].

For the direct-exposure external DAR (Figure 6a), a common method to improve fluid control is to increase the panel tilt as it has a strong effect on controlling fluid loss but results in taller receiver surfaces. Manifold designs and fluid stability have been studied to improve fluid control but without implementation in a demonstration plant [76]. Demonstrations of the external DAR concept using a molten carbonate salt have been reported by Bohn with thermal efficiencies on the order of $80-90 \%$ and heat transfer coefficients of about $3000 \mathrm{~W} / \mathrm{m}^{2} \cdot \mathrm{K}$ [93]. However, larger heat transfer coefficients on the order of $6500 \mathrm{~W} / \mathrm{m}^{2} \mathrm{~K}$ are expected for Reynolds numbers of 3000 . These early tests were conducted up to a temperature of approximately $700{ }^{\circ} \mathrm{C}$ and a flux of $43 \mathrm{~W} / \mathrm{cm}^{2}$. One major concern with respect to external 
DARs is the influence of wind on the falling film (making it unstable and resulting in hotspots or fluid loss) and fluid fouling from environmental exposure.

\section{Figure 6. Falling liquid films for heat absorption in (a) direct-exposure, external receivers for a surround field [82]; (b) direct-exposure, internal receivers for a surround field; (c) direct-exposure, internal receivers for a north-facing field [77]; and (d) indirect-exposure, internal film receivers for surround or north-facing fields.}

For an internal DAR (which reduces wind impact on the falling film), the solar flux is incident on a curtain of the flowing liquid film along the internal wall of the cavity, see Figure $6 b, c$ [94]. The heat-transfer medium enters the receiver at the top of the enclosure and travels radially down an inclined absorber sidewall. The receiver's inner absorber walls are heated by incident radiation entering through the face down aperture at the bottom of the enclosure. The liquid HTF film established on the absorber walls is semi-transparent to the radiation, allowing the walls to heat up (solar salt is transparent in the solar spectrum [77, 78] with absorption bands in the mid-infrared region [95]). As the liquid HTF travels down the absorber walls, convection heats the falling fluid. While the liquid is somewhat protected by its location in a cavity, it is exposed to the environmental conditions and wind. DARs have the potential to achieve higher receiver outlet temperatures than conventional salt-in-tube receivers [96] and is one of the primary reasons for its consideration. Initial studies of a face-down cavity receiver indicate that for a design power of $250 \mathrm{MW}_{\text {th }}$ with an inlet temperature of $385{ }^{\circ} \mathrm{C}$ and an outlet temperature of $620^{\circ} \mathrm{C}$, the reflection losses are $1.4 \%$ and the thermal radiation losses are $3.9 \%$ [94]. In spite of 
the open aperture, convection losses are estimated to be about $0.8 \%$ (following [97]) without wind due to the face-down concept, where the hot air is expected to stagnate inside the cavity. In practice, the convection losses may approach the radiation losses in magnitude [6]. The highest reflection losses occur when the absorber walls approach a vertical orientation. However, increasing inclination also increases absorber wall height and overall receiver surface area for additional losses. These competing effects drive the absorber wall inclination to an optimum angle. Design point efficiencies have been projected to be as high as $94.5 \%$ for an internal, direct exposure, falling film receiver. Additional configurations of the internal DAR approach include rotating or inclined absorber walls to increase efficiency [94]. The inclined walls can significantly reduce reflection losses but only slightly increase thermal radiation losses. Rotation mitigates excessive temperature variation in the fluid and increases film stability. The variation of the angular velocity allows different operating strategies. The standard strategy intends to apply angular velocities below the velocity for which the liquid film would start to flow upward on the inclined plane. For non-rotating absorber wall, overheating of the HTF can be avoided by mass flow control whereby higher flow rates are supplied in areas of highest flux. Concerns for a DAR (internal or external) mainly stem from the exposure of the salt to the environment as the working fluid can be prone to contamination, film instability and wind effects. Despite these concerns, one projection is that the annual power production using a DAR can be up to $14 \%$ greater than that of a comparable tube receiver [98].

To avoid the weaknesses of direct-absorption techniques and the exposure of the receiver working fluid to the environment, indirect-exposure internal film receiver designs have been proposed wherein the liquid film is on an internal surface of an inclined cavity wall (Figure 6d). In this approach, the wall is illuminated (heated) by concentrated flux and the film in contact 
with the backside of this wall is the mechanism of heat transfer from the irradiated surface. Numerous potential advantages of the internal film receiver as compared to salt-in-tube and DAR receivers have been outlined [99]. Since the receiver fluid is not used as a volumetric absorber, no dopants are required. Projections of a $6 \%$ system cost reduction versus salt-in-tube approaches have been made due to its simplicity in manufacturing and assembly [100]. This cost reduction is largely due to the receiver weight reduction by replacing a tube bundle with a thin plate and a smaller pump requirement (from reduced pressure losses). The material reduction is also expected to reduce startup times. Initial testing of this design concept yielded efficiency values near $60 \%$ at incident powers from $240-577 \mathrm{~kW}$; efficiencies greater than $80 \%$ are anticipated through straightforward design improvements [101].

A slight internal pressure, provided by air, between the receiver panel and insulated backing plate enables the receiver surface to maintain its shape and integrity under nonuniform incident-flux distributions across the receiver's face (Figure 6d) [99]. The resulting temperature gradients in the panel and thermal stresses are of the primary concerns for implementing this approach. A funnel-shaped internal film receiver also has appeal in that thermal expansion concerns would be mitigated by the curvature. Although a pump is required to lift the fluid to the receiver, gravity drives the liquid flow within the receiver and reduces the pumping requirements relative to a liquid-based, tubular receiver. A significant benefit of internal film receivers is that the receiver does not operate at high pressures as in the tubular receiver, even though it operates at a pressure slightly above ambient. At elevated temperatures, where the alloy strength decreases, the lower system pressures result in lower stress. Further, finned structures could be added on the containment wall to improve heat penetration into the internal film. A face down aperture minimizes convection losses, however, for best field efficiencies, an 
inclined aperture is preferred. The optimum aperture angle is somewhere between these competing receiver and field efficiencies [94]. Additional performance improvement is possible through hybrid cavity/external designs to further reduce thermal losses.

\section{Solid Particle Receivers}

Falling solid particle receivers were proposed in the 1980's [102] as a means to increase receiver outlet temperatures to over $1000{ }^{\circ} \mathrm{C}$ with inherent storage capabilities of the solid particles. Sand-like ceramic particles fall through a cavity receiver and are directly irradiated by concentrated sunlight. Once heated, the particles may be stored in an insulated tank and/or used to heat a secondary working fluid (e.g., steam, $\mathrm{CO}_{2}$, air) for the power cycle (see Figure 7). Because the solar energy is directly absorbed in the sand-like working fluid, the flux limitations associated with tubular central receivers (high stresses resulting from the containment of high temperature, high pressure fluids) are avoided. The falling particle receiver appears well-suited for scalability ranging from $10-100 \mathrm{MW}_{\mathrm{e}}$ power-tower systems [103].

\section{Figure 7. Falling particle receiver system with integrated storage and heat exchange.}

Although a number of analytical and laboratory studies have been performed on the falling particle receiver since its inception in the 1980's [102-118], only one set of on-sun tests of a simple falling particle receiver has been performed [114]. Those preliminary tests, which did not optimize the configuration of the receiver aperture, only achieved $50 \%$ thermal efficiency, and the increase in particle temperature was $\sim 250^{\circ} \mathrm{C}$ from ambient conditions. Methods for increasing the temperature of the particles include the use of recirculation [111, 112] and other means to increase the residence time of the particles within the concentrated beam (e.g., obstructions, inclined plates) [109]. The thermal efficiency can be increased by increasing 
the concentration ratio and by reducing radiative and convective losses through optimization of the aperture size, use of aerowindows [117], and increasing the absorptance of the solid particles. Desirable properties of the solid particles include high packing density, high heat capacity, resistance to mechanical and thermal shock, resistance to sintering and agglomeration, corrosion resistance in air and other media, high solar absorptance, low thermal emittance, low cost, and wide availability [102]. Particle conveyance methods (elevators and lifts), storage, and effective particle-to-working-fluid heat exchangers $[119,120]$ also require further research. Computational fluid dynamics models of the falling particle receiver have been developed to assist in predicting the performance of these systems [108, 116, 117, 121]. Recent studies are aimed at advancing solid particle receiver technology that will improve the performance and efficiency through the development of novel features and components (e.g., recirculation, increased residence time, solid/fluid heat exchangers, storage, fluidized bed, particles).

\section{Summary and Conclusions}

This paper has reviewed several high-temperature receiver designs and technologies amenable to central receiver power tower systems. While much work has been done on receiver concepts to date, only a few concepts have been adopted for full demonstration in a plant. The most common is that of a tubular receiver with either a liquid or gas/liquid working fluid. The draw to higher turbine efficiencies and corresponding higher temperatures requires receiver efficiency improvements and, in many cases, a change in working fluid. A logical, but nevertheless challenging, approach would be to leverage existing tubular receivers for use at higher temperatures (and pressures) with alternate working fluids. Concerns regarding the materials that enable this change in working fluid exist largely due to cost of nickel-alloyed steels and long-term operation. Thus, a window of opportunity exists wherein alternative 
receiver approaches currently exists. A resurgence of solid-particle receivers is occurring as corrosion and material interaction appears favorable for this approach. However, particle conveyance, attrition, and transport remain a challenging prospect. Air receivers continue to have the highest operating temperatures deployed to date but suffer from a low heat capacity and require heat exchange for storage.

Table 1 provides a summary of the receivers considered in this work and outlines the benefits and challenges associated with them. For liquid and gas working fluids, tubular receivers still appear to have a place in future CSP plants. Selection of the working fluid for the receiver (and its capability for storage) will likely be determined by the hours of storage required. For particle receivers, a number of receiver designs require further consideration, and efforts are underway to improve efficiencies and overall performance.

\section{Table 1. Summary of receiver designs.}

\section{Acknowledgments}

The authors thank Alan Kruizenga for his edits and input. Sandia National Laboratories is a multi-program laboratory managed and operated by Sandia Corporation, a wholly owned subsidiary of Lockheed Martin Corporation, for the U.S. Department of Energy's National Nuclear Security Administration under contract DE-AC04-94AL85000.

\section{References}

[1] Kolb, G.J., Ho, C.K., Mancini, T.R., Gary, J.A., 2011, Power Tower Technology Roadmap and Cost Reduction Plan, SAND2011-2419, Sandia National Laboratories, Albuquerque, NM.

[2] Bradshaw, R.W. and R.W. Carling, 1987, A Review of the Chemical and PhysicalProperties of Molten Alkali Nitrate Salts and Their Effect on Materials for Solar Central Receivers, Journal of the Electrochemical Society, 134(8B), p. C510-C511. 
[3] Freeman, E.S., 1956, The kinetics of the thermal decomposition of sodium nitrate and of the reaction between sodium nitrite and oxygen, Journal of Physical Chemistry, 60(11), p. 1487-1493.

[4] Ho, C.K., A.R. Mahoney, A. Ambrosini, M. Bencomo, A. Hall, and T.N. Lambert, 2012, Characterization of Pyromark 2500 for High-Temperature Solar Receivers, in proceedings of the ASME 2012 Energy Sustainability and Fuel Cell Conference, ESFuelCell2012-91374, San Diego, CA, July 23-26, 2012.

[5] Pacheco, J.E., 2002, Final Test and Evaluation Results from the Solar Two Project, SAND2002-0120, Sandia National Laboratories, Albuquerque, NM.

[6] Falcone, P.K., 1986, A handbook for solar central receiver design, SAND86-8009, Sandia National Laboratories, Livermore, CA.

[7] Christian, J.M. and C.K. Ho, 2012, CFD Simulation and Heat Loss Analysis of the Solar Two Power Tower Receiver, in Proceedings of the ASME 2012 Energy Sustainability and Fuel Cell Conference, San Diego, CA, July 23-26, 2012.

[8] Avila-Marin, A.L., 2011, Volumetric receivers in Solar Thermal Power Plants with Central Receiver System technology: A review, Solar Energy, 85(5), p. 891-910.

[9] Hennecke, K., P. Schwarzbozi, S. Alexopoulos, J. Gottsche, B. Hoffschmidt, M. Beuter, G. Koll, and T. Hartz, 2008, Solar power tower Julich: the first test and demonstration plant for open volumetric receiver technology in Germany, in SolarPACES, Las Vegas, NV, March 4-7, 2008.

[10] Zunft, S., M. Hanel, M. Kruger, V. Dreissigacker, F. Gohring, and E. Wahl, 2011, Julich Solar Power Tower-Experimental Evaluation of the Storage Subsystem and Performance Calculation, Journal of Solar Energy Engineering-Transactions of the Asme, 133(3).

[11] Chavez, J.M. and C. Chaza, 1991, Testing of a Porous Ceramic Absorber for a Volumetric Air Receiver, Solar Energy Materials, 24(1-4), p. 172-181.

[12] Menigault, T., G. Flamant, and B. Rivoire, 1991, Advanced High-Temperature 2-Slab Selective Volumetric Receiver, Solar Energy Materials, 24(1-4), p. 192-203.

[13] Variot, B., T. Menigault, and G. Flamant, 1994, Modeling and Optimization of a 2-Slab Selective Volumetric Solar Receiver, Solar Energy, 53(4), p. 359-368.

[14] Pitzpaal, R., J. Morhenne, and M. Fiebig, 1991, A New Concept of a Selective Solar Receiver for High-Temperature Applications, Solar Energy Materials, 24(1-4), p. 293306.

[15] Marcos, M.J., M. Romero, and S. Palero, 2004, Analysis of air return alternatives for CRS-type open volumetric reciever, Energy, 29(5-6), p. 677-686.

[16] Kribus, A., H. Ries, and W. Spirkl, 1996, Inherent limitations of volumetric solar receivers, Journal of Solar Energy Engineering-Transactions of the Asme, 118(3), p. 151155.

[17] PitzPaal, R., B. Hoffschmidt, M. Bohmer, and M. Becker, 1997, Experimental and numerical evaluation of the performance and flow stability of different types of open volumetric absorbers under non-homogeneous irradiation, Solar Energy, 60(3-4), p. 135150.

[18] Karni, J., A. Kribus, R. Rubin, and P. Doron, 1998, The "porcupine": A novel high-flux absorber for volumetric solar receivers, Journal of Solar Energy EngineeringTransactions of the Asme, 120(2), p. 85-95.

[19] Miller, F. and R. Koenigsdorff, 1991, Theoretical-Analysis of a High-Temperature Small-Particle Solar Receiver, Solar Energy Materials, 24(1-4), p. 210-221. 
[20] Miller, F.J. and R.W. Koenigsdorff, 2000, Thermal modeling of a small-particle solar central receiver, Journal of Solar Energy Engineering-Transactions of the Asme, 122(1), p. 23-29.

[21] Abdelrahman, M., P. Fumeaux, and P. Suter, 1979, Study of Solid-Gas-Suspensions Used for Direct Absorption of Concentrated Solar-Radiation, Solar Energy, 22(1), p. 45-48.

[22] Hunt, A., 1978, Small-Particle Heat Exchangers, Lawrence Berkeley Laboratory Report LBL-7841, Berkeley, CA.

[23] Hunt, A. and T. Brown, 1983, Solar Test Results of an Advanced Direct Absorption High-Temperature Gas Receiver (SPHER), in Proc. of the ISES Solar World Congress, Perth, Australia,

[24] Bienert, W.B., H. Rind, and A.A. Wolf, 1979, Conceptual Design of an Open Cycle Air Brayton Solar Receiver: Phase 1 Final Report, DTM-79-1 Prepared under Contract No. 955135 for California Institute of Technology Jet Propulsion Laboratory, Dynatherm Corporation, Cockeysville, MD.

[25] Bechtel National Inc., 1981, Preliminary Heat Pipe Testing Program: Final Technical Report, Contract No. DE-AC03-79SF 10756, San Francisco, CA.

[26] Heller, P., M. Pfander, T. Denk, F. Tellez, A. Valverde, J. Fernandez, and A. Ring, 2006, Test and evaluation of a solar powered gas turbine system, Solar Energy, 80(10), p. 12251230.

[27] Fan, Z.L., Y.M. Zhang, D.Y. Liu, J. Wang, and W. Liu, 2007, Discussion of mechanical design for pressured cavity-air-receiver in solar power tower system, Proceedings of Ises Solar World Congress 2007: Solar Energy and Human Settlement, Vols I-V, p. 18681872.

[28] Amsbeck, L., R. Buck, P. Heller, J. Jedamski, and R. Uhlig, 2008, Development of a Tube Receiver for a Solar-Hybrid Microturbine System, in Proceedings of the 2008 SolarPACES Conference, Las Vegas, NV, March 4-7, 2008.

[29] Amsbeck, L., G. Helsch, M. Roger, and R. Uhlig, 2009, Development of a Broadband Antireflection Coated Transparent Silica Window for a Solar-Hybrid Microturbine Systems, in Proceedings of SolarPACES 2009, Berlin, Germany, September 15 - 18, 2009.

[30] Heller, P., et al., 2009, Development of a Solar-Hybrid Microturbine System for a MiniTower, in Proceedings of SolarPACES 2009, Berlin, Germany, September 15 - 18, 2009.

[31] Hischier, I., D. Hess, W. Lipinski, M. Modest, and A. Steinfeld, 2009, Heat Transfer Analysis of a Novel Pressurized Air Receiver for Concentrated Solar Power Via Combined Cycles, Ht2009: Proceedings of the Asme Summer Heat Transfer Conference 2009, Vol 1, p. 105-112.

[32] Amsbeck, L., et al., 2010, Test of a Solar-Hybrid Microturbine System and Evaluation of Storage Deployment, in Proceedings of SolarPACES 2010, Perpignan, France, September $21-24,2010$.

[33] Uhlig, R., 2011, Transient Stresses at Metallic Solar Tube Receivers, in Proceedings of SolarPACES 2011, Granada, Spain, September 20 - 23, 2011.

[34] Kolb, G.J., 2011, An Evaluation of Possible Next-Generation High-Temperature MoltenSalt Power Towers, Sandia National Laboratories, SAND2011-9320, Albuquerque, NM.

[35] Seidel, W., Model developmenet and annual simulation of the supercritical carbon dioxide Brayton cycle for concentrating solar power applications, in Mechanical Engineering2010, University of Wisconsin-Madison. 
[36] Angelino, G., 1968, Carbon dioxide condensation cycles for power production, Journal of Engineering for Power, 90(3), p. 287-296.

[37] Angelino, G., 1969, Real gas effects in carbon dioxide cycles, in ASME International Gas Turbine Conference and Products Show GT-102, Cleveland, OH, March 10-13, 1969.

[38] Dostal, V., A supercritical carbon dioxide cycle for next generation nuclear reactors, in Nuclear Engineering2004, Massachusetts Institute of Technology.

[39] Dostal, V., P. Hejzlar, and M.J. Driscoll, 2006, High-performance supercritical carbon dioxide cycle for next-generation nuclear reactors, Nuclear Technology, 154(Compendex), p. 265-282.

[40] Dostal, V., P. Hejzlar, and M.J. Driscoll, 2006, The supercritical carbon dioxide power cycle: Comparison to other advanced power cycles, Nuclear Technology, 154(Compendex), p. 283-301.

[41] Moisseytsev, A. and J.J. Sienicki, 2010, Extension of supercritical carbon dioxide Brayton cycle for application to the very high temperature reactor, in International Congress on the Advances in Nuclear Power Plants, San Diego, CA, June 13-17, 2010.

[42] Turchi, C.S., 2009, Supercritical $\mathrm{CO}_{2}$ for application in concentrating solar power systems, in SCCO2 Power Cycle Symposium, Troy, NY, April 29-30, 2009.

[43] Glatzmaier, G.C. and C.S. Turchi, 2009, Supercritical $\mathrm{CO}_{2}$ as a heat transfer and power cycle fluid for CSP systems, in ASME Energy Sustainability, San Francisco, CA, July 1923, 2009.

[44] Kelly, B., 2010, Advanced thermal storage for central receivers with supercritical coolants, DE-FG36-08GO18149, Abengoa Solar, Inc., Lakewood, CO.

[45] Delussu, G., 2012, A qualitative thermo-fluid-dynamic analysis of a $\mathrm{CO}_{2}$ solar pipe receiver, Solar energy, 86(3), p. 926-934.

[46] Radosevich, L.G., 1988, Final Report on the Power Production Phase of the $10 \mathrm{MWe}$ Solar Thermal Central Receiver Pilot Plant, SAND87-8022, Sandia National Laboratories, Albuquerque, NM.

[47] Smith, D.C., 1992, Design and optimization of tube-type receiver panels for molten salt application, in ASME International Solar Energy Conference, Maui, HI, USA, April 5-9, 1992.

[48] Smith, D.C. and J.M. Chavez, 1987, A final report on the phase I testing of a molten-salt cavity receiver, SAND87-2290, Sandia National Laboratories, Albuquerque, NM.

[49] Drouot, L.P. and M.J. Hillairet, 1984, The Themis Program and the 2500-Kw Themis Solar Power-Station at Targasonne, Journal of Solar Energy Engineering-Transactions of the Asme, 106(1), p. 83-89.

[50] Schiel, W.J.C. and M.A. Geyer, 1988, Testing an external sodium receiver up to heat fluxes of $2.5 \mathrm{MW} / \mathrm{m}^{2}$ : Results and conclusions from the IEA-SSPS high flux experiment conducted at the central receiver system of the Plataforma Solar de Almeria (Spain), Solar energy, 41(3), p. 255-265.

[51] Forsberg, C.W., P.F. Peterson, and H.H. Zhao, 2007, High-temperature liquid-fluoridesalt closed-Brayton-cycle solar power towers, Journal of Solar Energy EngineeringTransactions of the Asme, 129(2), p. 141-146.

[52] Singer, C., R. Buck, R. Pitz-Paal, and H. Muller-Steinhagen, 2010, Assessment of solar power tower driven ultrasupercritical steam cycles applying tubular central receivers with varied heat transfer media, Journal of Solar Energy Engineering, 132(4), p. 041010 1-12. 
[53] Forsberg, C.W., P.F. Peterson, and H. Zhao, 2007, High-temperature liquid-fluoride-salt closed-Brayton-cycle solar power towers, Journal of Solar Energy Engineering, 129, p. 141-146.

[54] Ambrosini, A., T.N. Lambert, M. Bencomo, A. Hall, K. vanEvery, N.P. Siegel, and C.K. Ho, 2011, Improved high temperature solar absorbers for use in concentrating solar power central receiver applications, in Energy Sustainability, Washington D.C., August 7-10, 2011.

[55] Kennedy, C.E. and N.R.E. Laboratory, 2002, Review of mid- to high-temperature solar selective absorber materials, NREL/TP-520-31267, National Renewable Energy Laboratory, Golden, $\mathrm{CO}$.

[56] Epstein, M., D. Liebermann, M. Rosh, and A.J. Shor, 1991, Solar testing of $2 \mathrm{MW}_{\text {th }}$ water/steam receiver at the Weizmann Institute solar tower, Solar energy materials, 24(14), p. 265-278.

[57] Li, X., W. Kong, Z. Wang, C. Chang, and F. Bai, 2010, Thermal model and thermodynamic performance of molten salt cavity receiver, Renewable Energy, 35(5), p. 981-988.

[58] Ambrosek, J.W., Molten chloride salts for heat transfer in nuclear systems, in Nuclear Engineering and Engineering Physics2011, University of Wisconsin-Madison.

[59] Olson, L.C., Materials corrosion in molten LiF-NaF-KF eutectic salt, in Nuclear Engineering2009, University of Wisconsin: Madison.

[60] Littlewood, R. and E.J. Argent, 1961, Electrochemical studies of the behaviour of metals in fused chlorides, Electrochimica Acta, 4(2-4), p. 155-169.

[61] Williams, D.F., 2006, Assessment of Candidate Molten Salt Coolants for the NGNP/NHI Heat-Transfer Loop, ORNL/TM-2006/69, Oak Ridge National Laboratory,

[62] Williams, D.F., L.M. Toth, and K.T. Clarno, 2006, Assessment of Candidate Molten Salt Coolants for the Advanced High-Temperature Reactor (AHTR), ORNL/TM-2006/12, Oak Ridge National Laboratories,

[63] Coyle, R.T., T.M. Thomas, and P. Schissel, 1986, The Corrosion of Selected Alloys in Eutectic Lithium-Sodium-Potassium Carbonate at 900C, SERI/PR-255-2561, Solar Energy Research Institude, Golden, CO.

[64] Bradshaw, R.W. and D.E. Meeker, 1990, High-temperature stability of ternary nitrate molten salts for solar thermal energy systems, Solar energy materials, 21(1), p. 51-60.

[65] Stern, K.H., 2001, High temperature properties and thermal decomposition of inorganic salts with oxyanions, CRC Press, Boca Raton, Fla.

[66] Pacheco, J. and S.R. Dunkin, 1996, Assessment of molten-salt solar central-receiver freeze-up and recover events, in ASME International Solar Energy Conference, San Antonio, TX, March 31 - April 3, 1996.

[67] Pacheco, J.E., M.E. Ralph, and J.M. Chavez, 1995, Investigation of cold filling receiver panels and piping in molten-nitrate-salt central-receiver solar power plants, in ASME International Solar Energy Conference, Lahaina, Maui, HI, March 19-24, 1995.

[68] Pacheco, J.E., M.E. Ralph, J.M. Chavez, S.R. Dunkin, E.E. Rush, C.M. Ghanbari, and M.W. Matthews, 1994, Results of molten salt panel and component experiments for solar central receivers: cold fill, freeze/thaw, thermal cycling and shock, and instrumentation tests, SAND94-2525, Sandia National Laboratories, Albuquerque, NM.

[69] Kistler, B.L., 1986, Fatigue analysis of a solar central receiver design using measured weather data, SAND86-8017, Sandia National Laboratories, Livermore, CA. 
[70] Kolb, G.J., 2011, An evaluation of possible next-generation high-temperature molten-salt power towers, SAND2011-9320, Sandia National Laboratories, Albuquerque, NM.

[71] Siebers, D.L. and J.S. Kraabel, 1984, Estimating convective energy losses from solar central receivers, SAND84-8717, Sandia National Laboratories, Livermore, CA.

[72] Bergan, N.E., 1986, Testing of the molten salt electric experiment solar central receiver in an external configuration, SAND86-8010, Sandia National Laboratories, Livermore, CA.

[73] Persky, M.J. and M. Szczesniak, 2008, Infrared, spectral, directional-hemispherical reflectance of fused silica, Teflon polytetrafluoroethylene polymer, chrome oxide ceramic particle surface, Pyromark 2500 paint, Krylon 1602 paint, and Duraflect coating, Applied Optics, 47(10), p. 1389-1396.

[74] Ambrosini, A., T.N. Lambert, M. Bencomo, A. Hall, K. vanEvery, N.P. Siegel, and C.K. Ho, 2011, Improved High Temperature Solar Absorbers for Use in Concentrating Solar Power Central Receiver Applications, in proceedings of the ASME 2011 Energy Sustainability and Fuel Cell Conference, ESFuelCell2011-54241, Washington D.C., August 7-10, 2011.

[75] Hall, A., A. Ambrosini, and C. Ho, 2012, Solar Selective Coatings for Concentrating Solar Power Central Receivers, Advanced Materials \& Processes, 170(1), p. 28-32.

[76] Chavez, J.M., C.E. Tyner, and W.A. Couch, 1987, Direct absorption receiver flow testing and evaluation, SAND87-2875C, Sandia National Laboratories, Albuquerque, NM.

[77] Webb, B.W. and R. Viskanta, 1985, Analysis of heat transfer and solar radiation absorption in an irradiated, thin, falling molten salt film, Journal of Solar Energy Engineering, 107(2), p. 113-119.

[78] Drotning, W.D., 1977, Solar absorption properties of a high temperature directabsorbing heat transfer fluid, in Symposium on Thermophysical Properties, Gaithersburg, MD, May 10, 1977.

[79] Drotning, W.D., 1977, Optical properties of a solar-absorbing molten salt heat transfer fluid, SAND77-0938, Sandia National Laboratories, Livermore, CA.

[80] Drotning, W.D., 1978, Optical properties of solar-absorbing oxide particles suspended in a molten salt heat transfer fluid, Solar energy, 20(4), p. 313-319.

[81] Jorgensen, G., P. Schissel, and R. Burrows, 1986, Optical properties of high-temperature materials for direct absorption receivers, Solar energy materials, 14(3), p. 385-394.

[82] Bohn, M.S. and H.J. Green, 1989, Heat transfer in molten salt direct absorption receivers, Solar energy, 42(1), p. 57-66.

[83] Veeraragavan, A., A. Lenert, B. Yilbas, S. Al-Dini, and E.N. Wang, 2012, Analytical model for the design of volumetric solar flow receivers, International Journal of Heat and Mass Transfer, 55(4), p. 556-564.

[84] Halmann, M. and K. Zuckerman, 1988, Stability of molten nitrate salts containing light absorbing additives as solar flux absorbers, Solar energy materials, 17(4), p. 311-318.

[85] Yih, S.-M. and R.C. Seagrave, 1978, Hydrodynamic stability of thin liquid films flowing down an inclined plane with accompanying heat transfer and interfacial shear, AIChE Journal, 24(5), p. 803-810.

[86] Wang, K.Y., T.A. Newell, and R.J. Copeland, 1985, Film stability for direct absorption receivers, in Intersol 85, Proceedings of the Ninth Biennial Congress of the International Solar Energy Society, Montreal, Quebec, Canada, June 23-29, 1985. 
[87] Tyner, C.E., 1988, Status of the direct absorption receiver panel research experiment: salt flow and solar test requirements and plans, SAND88-2455, Sandia National Laboratories, Albuquerque, NM.

[88] Newell, T.A., K.Y. Wang, and R.J. Copeland, 1985, Film flow characteristics for direct absorption solar receiver surfaces, in ASME Heat Transfer and Fluid Flow in Solar Thermal Systems, Miami Beach, FL, USA, November 17-22, 1985.

[89] Faghri, A. and R.A. Seban, 1985, Heat transfer in wavy liquid films, International Journal of Heat and Mass Transfer, 28(2), p. 506-508.

[90] Faghri, A. and R.A. Seban, 1988, Heat and mass transfer to a turbulent liquid film, International Journal of Heat and Mass Transfer, 31(4), p. 891-894.

[91] Faghri, A. and R.A. Seban, 1989, Heat and mass transfer to a turbulent falling film - II, International Journal of Heat and Mass Transfer, 32(9), p. 1796-1798.

[92] Bohn, M.S. and S.H. Davis, 1993, Thermocapillary breakdown of falling liquid films at high Reynolds numbers, International Journal of Heat and Mass Transfer, 36(7), p. 1875-1881.

[93] Bohn, M.S., 1987, Experimental investigation of the direct absorption receiver concept, Energy, 12(3,Äi4), p. 227-233.

[94] Wu, W., B. Gobereit, C. Singer, L. Amsbeck, and R. Pitz-Paal, 2011, Direct absorption receivers for high temperatures, in SolarPACES, Granada, Spain, September 20-23, 2011.

[95] Gruen, D.M., 1965, Fused-salt spectrophotometry, Quarterly Reviews, Chemical Society, 19(4), p. 349-368.

[96] Wu, S.F. and T.V. Narayama, 1988, Commercial direct absorption receiver design studies, SAND88-7038, Sandia National Laboratories, Albuquerque, NM.

[97] Paitoonsurikarn, S., K. Lovegrove, G. Hughes, and J. Pye, 2011, Numerical investigation of natural convection loss from cavity receivers in solar dish applications, Journal of Solar Energy Engineering, 133(2).

[98] Tracey, T.R., C.E. Tyner, and E.R. Weber, 1988, Potential of advanced-design solar central receiver power systems, SAND88-1923C, Sandia National Laboratories, Albuquerque, NM.

[99] Tracey, T., 1992, Potential of modular internal film receivers in molten salt central receiver solar power systems, in ASME International Solar Energy Conference, Maui, HI, April 5-9, 1992.

[100] Sanchez, M., G. Barrera, J. Leon, and J. Pacheco, 1997, Internal film receiver possibilities for the third generation central receiver technology, in International Solar Energy Conference, Solar Engineering, Washington, D.C., April 27-30, 1997.

[101] Leon, J., M. Sanchez, and J.E. Pacheco, 1999, Internal film receiver possibilities for the third generation of central receiver technology, Journal De Physique IV, 9, p. Pr3-525530.

[102] Falcone, P.K., J.E. Noring, and J.M. Hruby, 1985, Assessment of a Solid Particle Receiver for a High Temperature Solar Central Receiver System, SAND85-8208, Sandia National Laboratories, Livermore, CA.

[103] Kolb, G.J., R.B. Diver, and N. Siegel, 2007, Central-station solar hydrogen power plant, Journal of Solar Energy Engineering-Transactions of the ASME, 129(2), p. 179-183. 
[104] Chen, H.J., Y.T. Chen, H.T. Hsieh, G. Kolb, and N. Siegel, 2007, Numerical investigation on optimal design of solid particle solar receiver, Proceedings of the Energy Sustainability Conference 2007, p. 971-979.

[105] Chen, H.J., Y.T. Chen, H.T. Hsieh, and N. Siegel, 2007, Computational fluid dynamics modeling of gas-particle flow within a solid-particle solar receiver, Journal of Solar Energy Engineering-Transactions of the Asme, 129(2), p. 160-170.

[106] Chen, Z.Q., Y.T. Chen, and T.D. Tan, 2009, Numerical Analysis on the Performance of the Solid Solar Particle Receiver with the Influence of Aerowindow, in Proceedings of the ASME Fluids Engineering Division Summer Conference -2008, Vol 1, Pt a and B, Jacksonville, FL,

[107] Ho, C.K., M. Roeger, S.S. Khalsa, L. Amsbeck, R. Buck, N. Siegel, and G. Kolb, 2009, Experimental Validation of Different Modeling Approaches for Solid Particle Receivers, in SolarPACES 2009, SAND2009-4140C, Berlin, Germany, September 15-18, 2009.

[108] Ho, C.K., S.S. Khalsa, and N.P. Siegel, 2009, Modeling on-Sun Tests of a Prototype Solid Particle Receiver for Concentrating Solar Power Processes and Storage, in ES2009:

Proceedings of the ASME 3rd International Conference on Energy Sustainability, Vol 2, San Francisco, CA,

[109] Hruby, J.M., 1986, A Technical Feasibility Study of a Solid Particle Solar Central Receiver for High Temperature Applications, SAND86-8211, Sandia National Laboratories, Livermore, CA.

[110] Hruby, J.M. and B.R. Steele, 1986, A Solid Particle Central Receiver for Solar-Energy, Chemical Engineering Progress, 82(2), p. 44-47.

[111] Khalsa, S.S., J.M. Christian, G.J. Kolb, M. Roger, L. Amsbeck, C.K. Ho, N.P. Siegel, A.C. Moya, 2011, CFD Simulation and Performance Analysis of Alternative Designs for High-Temperature Solid Particle Receivers, in Proceedings of the ASME 2011 Energy Sustainability and Fuel Cell Conference, ESFuelCell2011-54430, Washington D.C., August 7-10, 2011.

[112] Roger, M., L. Amsbeck, B. Gobereit, and R. Buck, 2011, Face-Down Solid Particle Receiver Using Recirculation, in Journal of Solar Energy Engineering-Transactions of the Asme, 3, Aug.

[113] Siegel, N., G. Kolb, K. Kim, V. Rangaswamy, and S. Moujaes, 2007, Solid particle receiver flow characterization studies, Proceedings of the Energy Sustainability Conference 2007, p. 877-883.

[114] Siegel, N.P., C.K. Ho, S.S. Khalsa, and G.J. Kolb, 2010, Development and Evaluation of a Prototype Solid Particle Receiver: On-Sun Testing and Model Validation, Journal of Solar Energy Engineering-Transactions of the Asme, 132(2).

[115] Tan, T.D. and Y.T. Chen, 2009, Protection of an Aerowindow, One Scheme to Enhance the Cavity Efficiency of a Solid Particle Solar Receiver, in HT2009: Proceedings of the Asme Summer Heat Transfer Conference 2009, Vol 2, San Francisco, CA,

[116] Tan, T.D. and Y.T. Chen, 2010, Review of study on solid particle solar receivers, Renewable \& Sustainable Energy Reviews, 14(1), p. 265-276.

[117] Tan, T.D., Y.T. Chen, Z.Q. Chen, N. Siegel, and G.J. Kolb, 2009, Wind effect on the performance of solid particle solar receivers with and without the protection of an aerowindow, Solar Energy, 83(10), p. 1815-1827. 
[118] Gobereit, B., L. Amsbeck, and R. Buck, 2013, Operation Strategies for Falling Particle Receivers, in Proceedings of ASME 2013 7th International Conference on Energy Sustainability, ES-FuelCell2013-18354, Minneapolis, MN, July 14 - 19, 2013.

[119] Al-Ansary, H., S. Jeter, D. Sadowski, A. Alrished, M. Golob, A. El-Leathy, and Z. AlSuhaibani, 2011, Experimental Study of a Sand-Air Heat Exchanger for user with a High Temperature Solar Gas Turbine System, in SolarPACES 2011, Granada, Spain, September 20-23, 2011.

[120] Golob, M., D. Sadowski, and S. Jeter, 2010, Heat Transfer from Flat Surfaces to Moving Sand, in 2010 ASME Early Career Technical Conference, Atlanta, Georgia, October 1-2, 2010.

[121] Meier, A., 1999, A predictive CFD model for a falling particle receiver reactor exposed to concentrated sunlight, Chemical Engineering Science, 54(13-14), p. 2899-2905. 

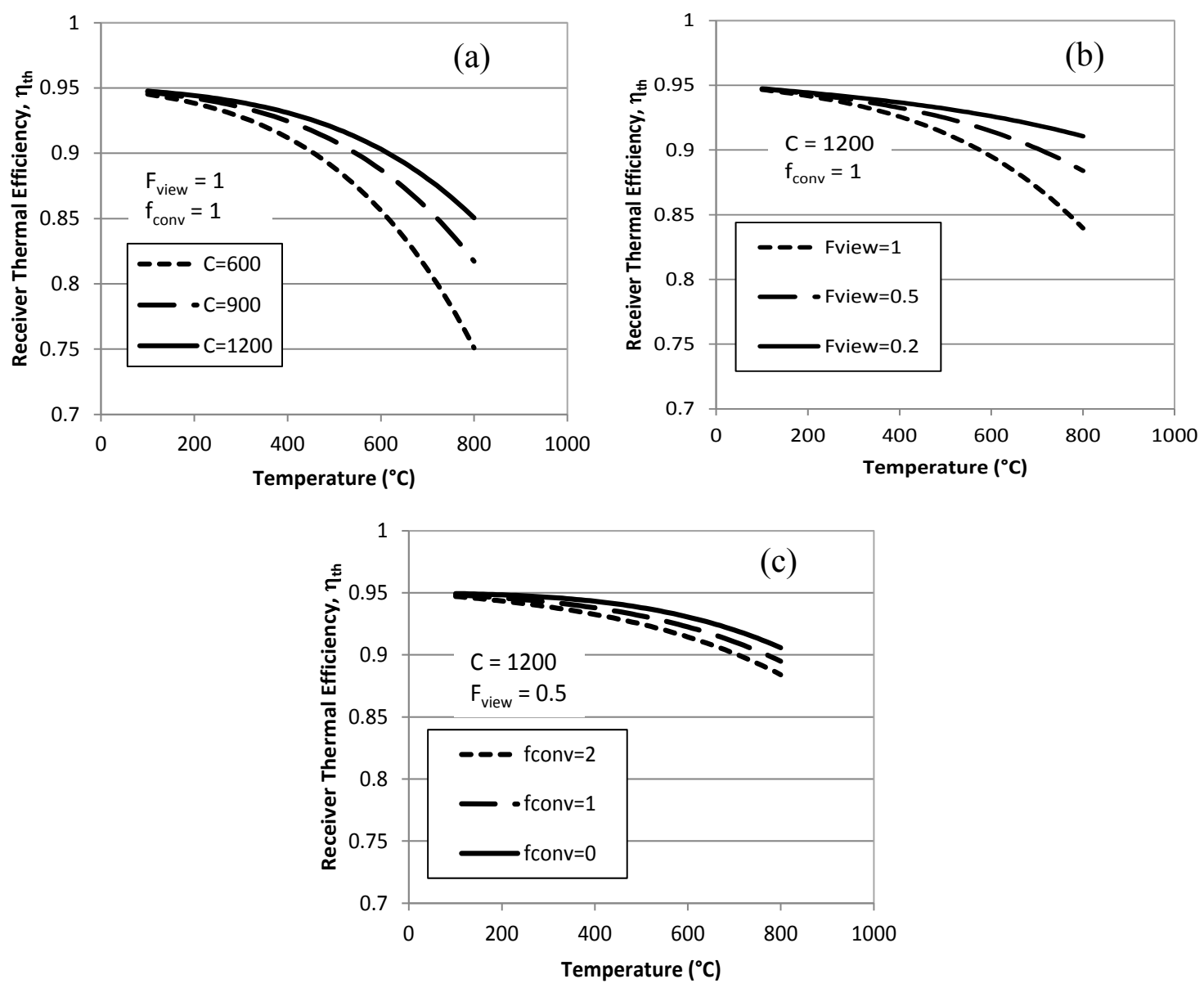

Figure 1. Plots of receiver thermal efficiency as a function of receiver surface temperature with varying concentration ratio (a), radiative view factor (b), and convective heat loss (c). 


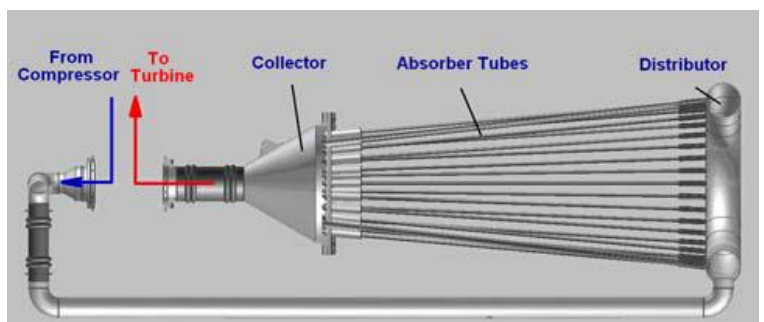

(a)
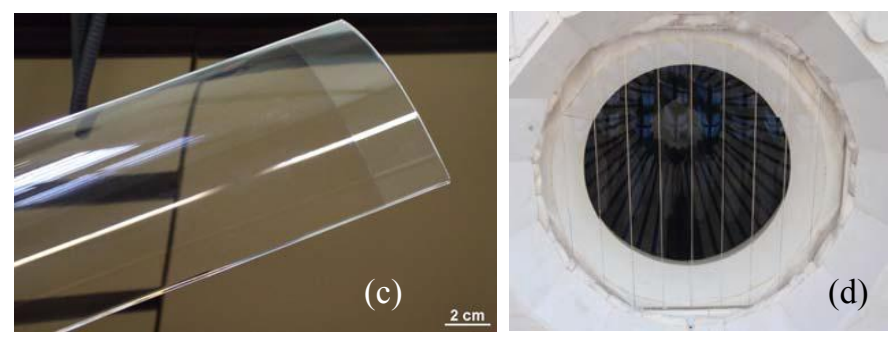
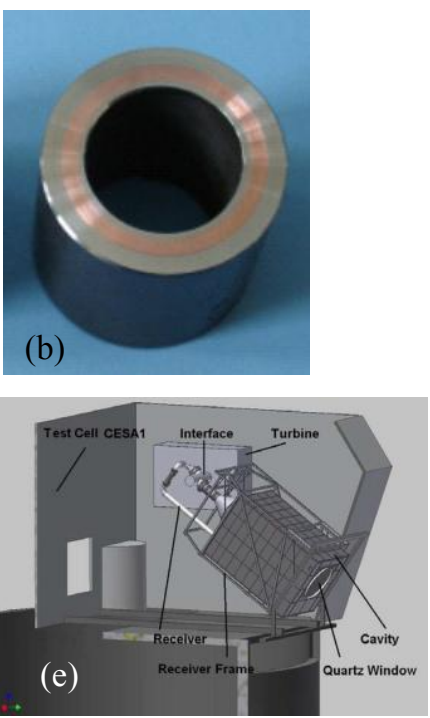

Figure 2. Design concepts from DLR: (a) tubular air-turbine receiver, (b) multi-layer tube with copper in between Inconel, (c)-(d) segmented parts of glass tubes to form a window on the receiver aperture, and (e) schematic of receiver and microturbine on top of a tower [30, 31, 33]. 

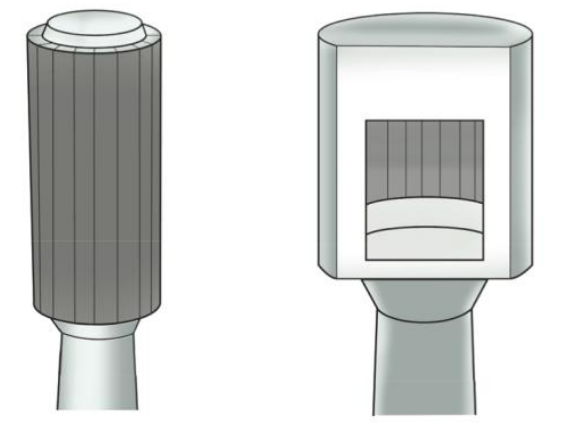

Figure 3. Schematics of tubular (left) external and (right) cavity receivers.

Figure 


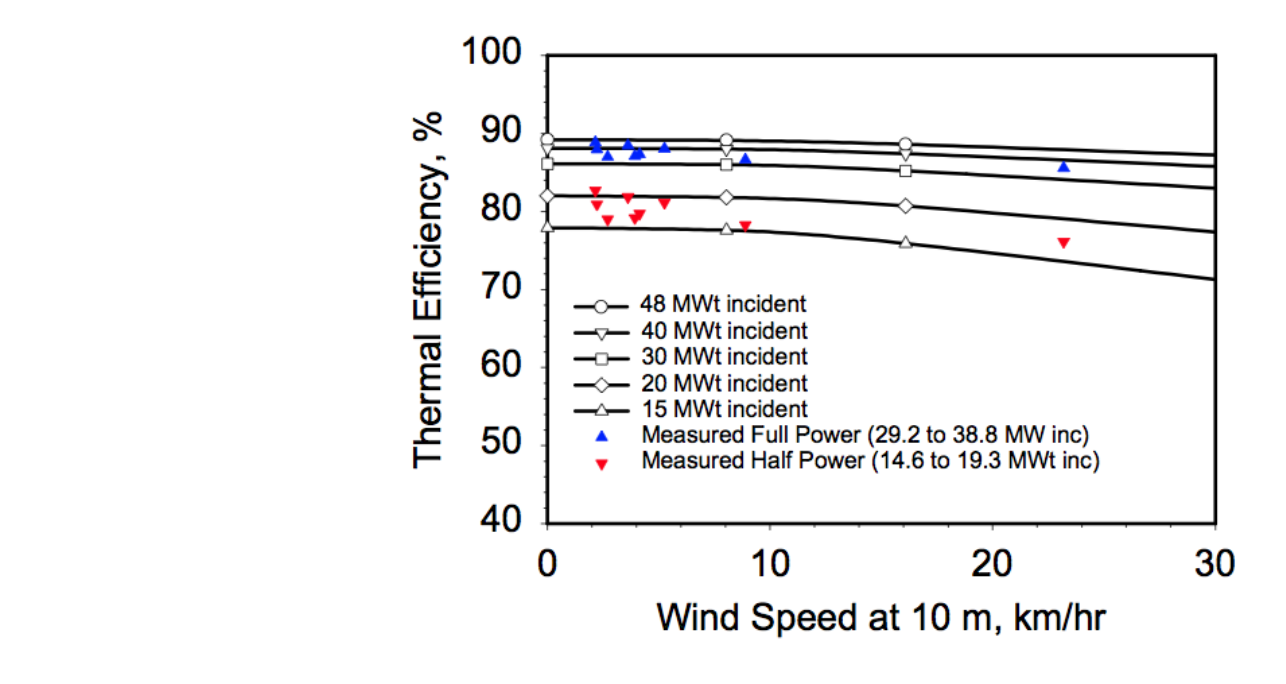

Figure 4. Calculated and measured receiver efficiency as a function of wind speed for Solar Two (from [6]).

Figure 4. Calculated and measured receiver efficiency as a function of wind speed for Solar Two (from [6]).

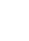

\section{.}

(1)

(a)

.

(1)

Solar Two (from [6]).
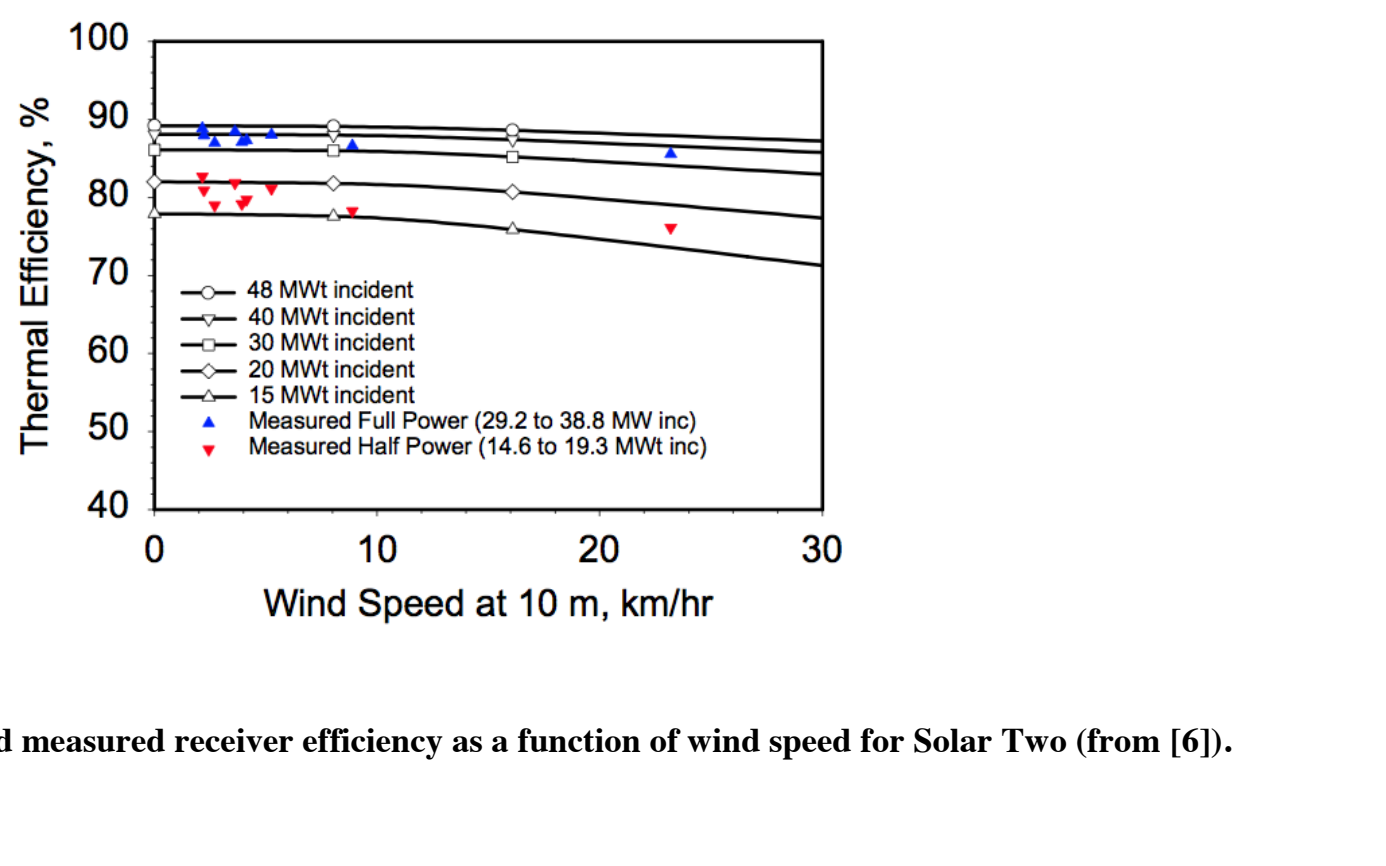


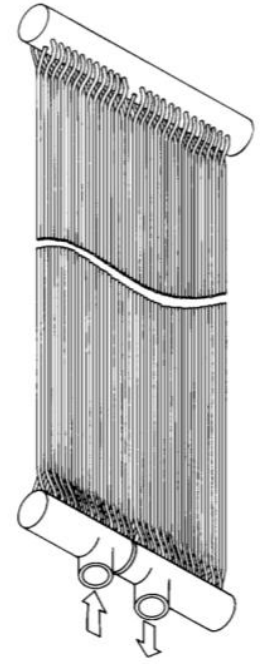

(a)

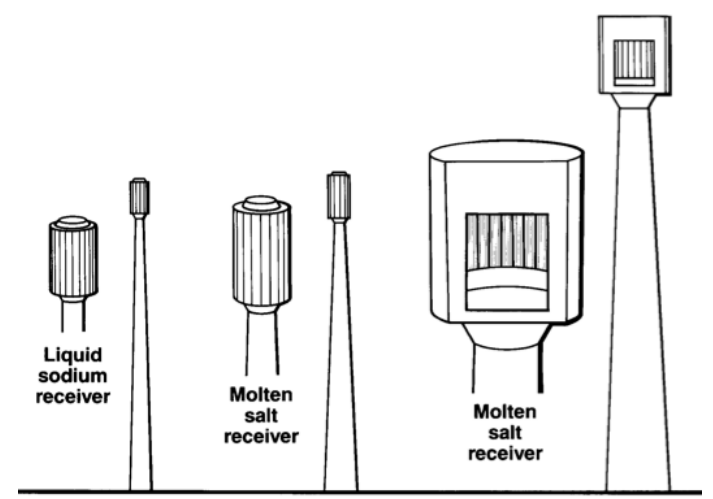

(b)

Figure 5. (a) Schematic of a tubular panel and (b) relative tower heights/receiver sizes for a liquid sodium and molten salt tubular receivers (from [7]). 


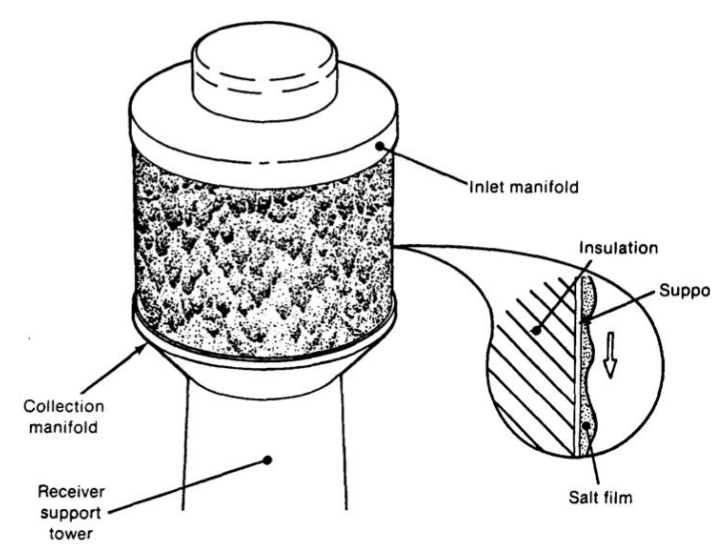

(a)

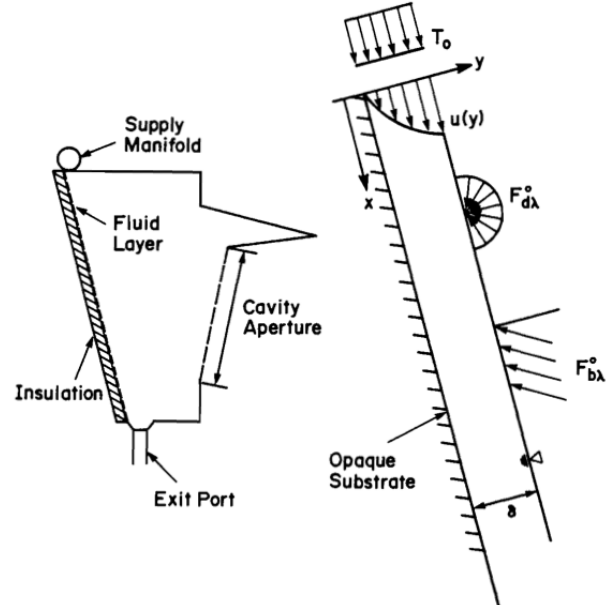

(c)

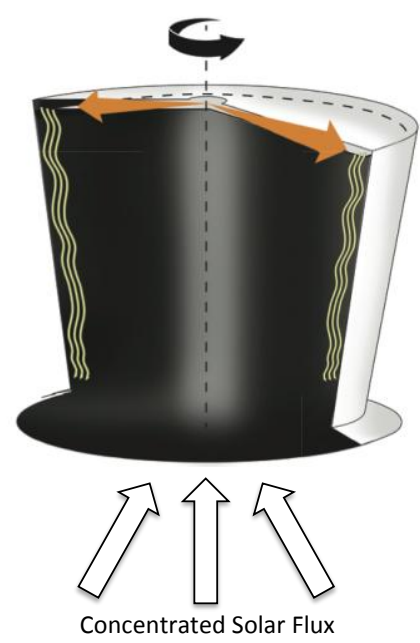

(b)

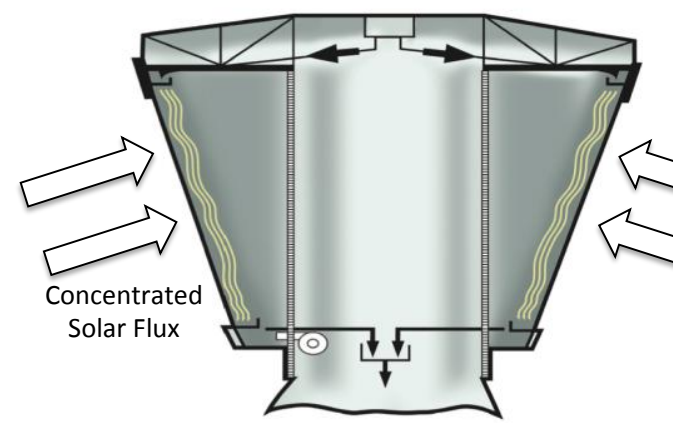

(d)

Figure 6. Falling liquid films for heat absorption in (a) direct-exposure, external receivers for a surround field [83]; (b) direct-exposure, internal receivers for a surround field; (c) direct-exposure, internal receivers for a north-facing field [78]; and (d) indirect-exposure, internal film receivers for surround or north-facing fields. 


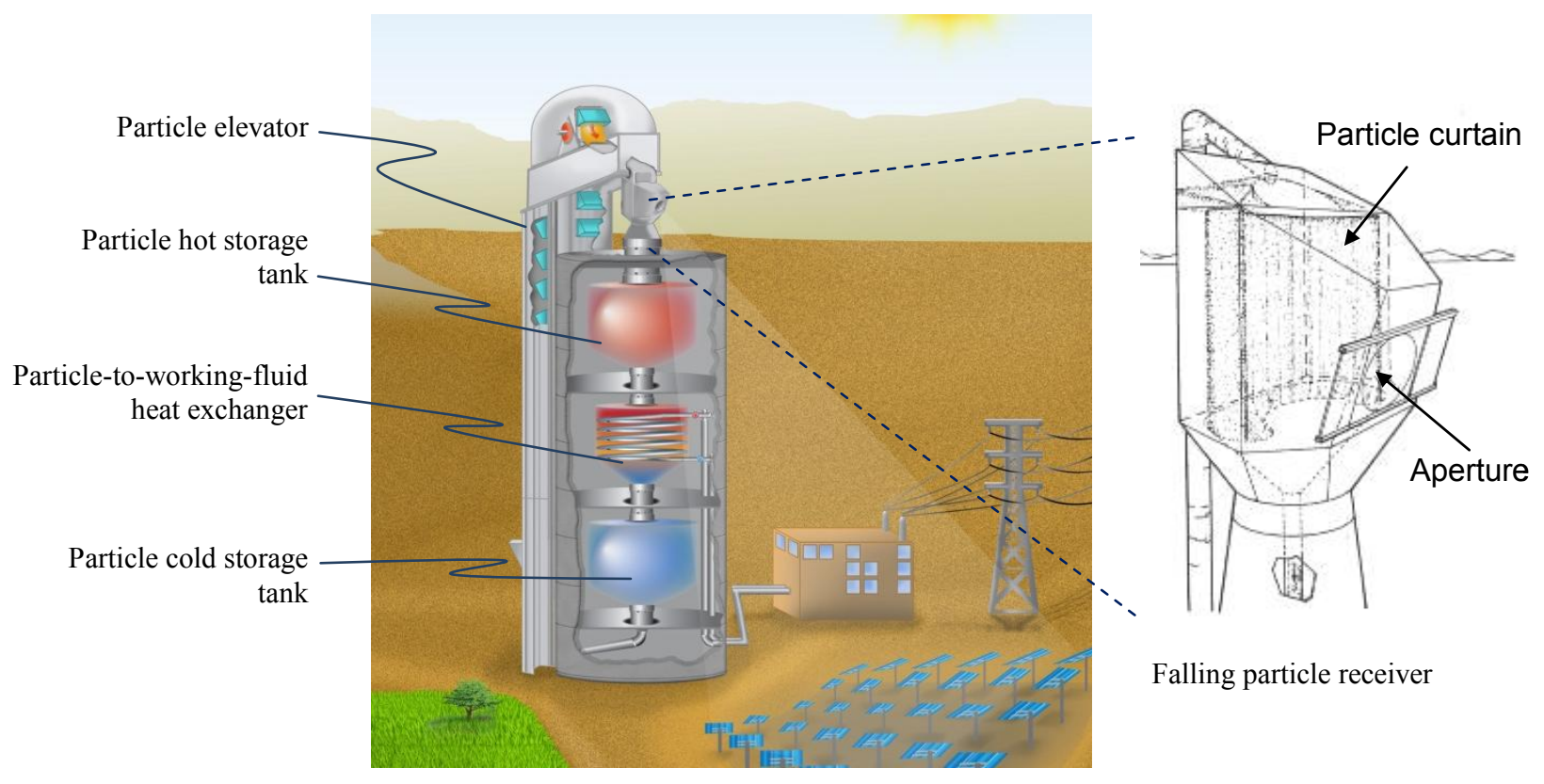

Figure 7. Falling particle receiver system with integrated storage and heat exchange. 
Table 1. Summary of receiver designs.

\begin{tabular}{|c|c|c|c|c|}
\hline $\begin{array}{c}\text { Receiver } \\
\text { Design }\end{array}$ & $\begin{array}{c}\text { Outlet } \\
\text { Temperature } \\
\text { / Thermal } \\
\text { Efficiency }\end{array}$ & Benefits & Challenges / Research Needs & References \\
\hline \multicolumn{5}{|c|}{ Gas Receivers } \\
\hline $\begin{array}{l}\text { Volumetric } \\
\text { Air Receiver }\end{array}$ & $\begin{array}{l}>700^{\circ} \mathrm{C} / \\
\sim 50-60 \%\end{array}$ & $\begin{array}{l}\text { Capable of achieving } \\
\text { high temperatures, } \\
\text { simple and flexible } \\
\text { construction }\end{array}$ & $\begin{array}{l}\text { Material durability, flow } \\
\text { instability, radiative heat loss, } \\
\text { low thermal efficiency, long- } \\
\text { term storage }\end{array}$ & {$[8,11-17]$} \\
\hline $\begin{array}{l}\text { Small } \\
\text { Particle Air } \\
\text { Receiver }\end{array}$ & $\begin{array}{l}>700^{\circ} \mathrm{C} / \\
\sim 80-90 \% \\
\text { (theoretical) }\end{array}$ & $\begin{array}{l}\text { Capable of achieving } \\
\text { high temperatures, } \\
\text { volumetric gas } \\
\text { absorption of energy }\end{array}$ & $\begin{array}{l}\text { Requires window for pressurized } \\
\text { receivers, solid-gas suspension } \\
\text { system to maintain desired } \\
\text { particle concentration and } \\
\text { temperature, long-term storage }\end{array}$ & [19-23] \\
\hline $\begin{array}{l}\text { Tubular Gas } \\
\text { Receiver }\end{array}$ & $\begin{array}{l}>800^{\circ} \mathrm{C} / \\
\sim 80-85 \% \\
\text { (theoretical) } \\
\sim 40 \% \\
\text { (prototype } \\
\text { test, }[32] \text { ) }\end{array}$ & $\begin{array}{l}\text { Capable of achieving } \\
\text { high temperatures and } \\
\text { gas pressures; heat- } \\
\text { pipes can provide } \\
\text { effective and compact } \\
\text { heat transfer to gas }\end{array}$ & $\begin{array}{l}\text { High radiative and convective } \\
\text { heat loss, low thermal efficiency, } \\
\text { need improved heat transfer } \\
\text { from irradiated tubes to gas, } \\
\text { material durability, long-term } \\
\text { storage }\end{array}$ & [24-34] \\
\hline \multicolumn{5}{|c|}{ Liquid Receivers } \\
\hline $\begin{array}{l}\text { Tubular } \\
\text { Liquid } \\
\text { Receiver }\end{array}$ & $\begin{array}{l}>600^{\circ} \mathrm{C}^{*} / \\
\sim 80-90 \%\end{array}$ & $\begin{array}{l}\text { Contained liquid; } \\
\text { demonstrated } \\
\text { performance; can } \\
\text { accommodate } \\
\text { potentially high } \\
\text { pressures }\end{array}$ & $\begin{array}{l}\text { Thermal expansion; material } \\
\text { compatibility; increased pressure } \\
\text { requirements to manage pressure } \\
\text { drop across receiver panel; } \\
\text { potential for tube solidification } \\
\text { and plugging }\end{array}$ & $\begin{array}{l}{[5,6,47} \\
48,50,52 \\
56,57,66- \\
68,71,72]\end{array}$ \\
\hline $\begin{array}{l}\text { Falling Film } \\
\text { Receiver } \\
\text { (Direct } \\
\text { Exposure) }\end{array}$ & $\begin{array}{l}>600^{\circ} \mathrm{C}^{*} / 80- \\
90 \% \text { (external } \\
\text { DAR, } \\
\text { experimental } \\
[93]), \\
\sim 94 \% \\
\text { (internal } \\
\text { DAR, } \\
\text { theoretical } \\
{[94] \text { ) }}\end{array}$ & $\begin{array}{l}\text { Higher receiver outlet } \\
\text { temperatures; reduced } \\
\text { thermal resistance and } \\
\text { startup time through } \\
\text { direct absorption; lower } \\
\text { pumping losses }\end{array}$ & $\begin{array}{l}\text { Film stability in exposed } \\
\text { environments; complexity of } \\
\text { rotating body; fluid impurities } \\
\text { and integrity in exposed } \\
\text { environments; absorber wall } \\
\text { flatness during thermal } \\
\text { expansion. }\end{array}$ & $\begin{array}{l}{[76,77,85-} \\
91,93,94 \\
96,98]\end{array}$ \\
\hline $\begin{array}{l}\text { Falling Film } \\
\text { Receiver } \\
\text { (Indirect } \\
\text { Exposure) }\end{array}$ & $\begin{array}{l}>600^{\circ} \mathrm{C}^{*} / \\
>80 \% \\
\text { (theoretical } \\
[101])\end{array}$ & $\begin{array}{l}\text { Reduced pumping } \\
\text { losses; faster response } \\
\text { time; capability of } \\
\text { operation at lower } \\
\text { insolation; simplicity of } \\
\text { fabrication; no need for } \\
\text { fluid doping }\end{array}$ & $\begin{array}{l}\text { Film stability and potential for } \\
\text { dry spots; absorber wall } \\
\text { flatness/shape integrity; flow } \\
\text { distribution across illuminated } \\
\text { surfaces to match incident flux; } \\
\text { thin sheet warping during } \\
\text { thermal expansion; } \\
\text { thermal loss reduction and } \\
\text { efficiency improvement by } \\
\text { exploring hybrid cavity/external } \\
\text { receiver concepts. }\end{array}$ & [99-101] \\
\hline
\end{tabular}




\begin{tabular}{|c|c|c|c|c|}
\hline \multicolumn{5}{|c|}{ Solid Particle Receivers } \\
\hline $\begin{array}{l}\text { Falling } \\
\text { Particle } \\
\text { Receivers }\end{array}$ & $\begin{array}{l}>800^{\circ} \mathrm{C} / \\
\sim 80-90 \% \\
\text { (simulation } \\
{[111,118] \text { ), }} \\
50 \% \\
\text { (prototype } \\
{[114] \text { ) }}\end{array}$ & $\begin{array}{l}\text { Capable of achieving } \\
\text { high temperatures, } \\
\text { direct irradiance of } \\
\text { particles reduces flux } \\
\text { limitations (on tubular } \\
\text { receivers), particles can } \\
\text { be stored at high } \\
\text { temperatures, particles } \\
\text { can be cheaper than } \\
\text { molten salt }\end{array}$ & $\begin{array}{l}\text { Need lower radiative and } \\
\text { convective heat losses, higher } \\
\text { concentration ratios, lower } \\
\text { particle attrition, greater solar } \\
\text { absorptance, lower thermal } \\
\text { emittance, increased particle } \\
\text { residence time, more effective } \\
\text { particle/fluid heat exchangers }\end{array}$ & {$[102-117]$} \\
\hline
\end{tabular}

*Dependent on fluid type 